Analitika: Jurnal Magister Psikologi UMA, Vol. 12 (2) Desember (2020)

ISSN: 2085-6601 (Print), ISSN: 2502-4590 (Online)

DOI: : http://doi.org/10.31289/analitika.v12i2.3631

\title{
ANALITIKA
}

Jurnal Magister Psikologi UMA

Available online http://ojs.uma.ac.id/index.php/analitika

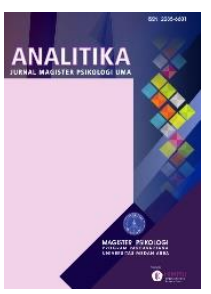

Intervensi Digital untuk Siswa yang Mengalami Gangguan Kesulitan Belajar

\section{Digital Intervention for Students with Learning Disabilities}

\author{
Maulana Arif Muhibbin* \& Wiwin Hendriani \\ Program Magister Psikologi , Fakultas Psikologi, Universitas Airlangga, Indonesia
}

Diterima: 25 Maret 2020, disetujui: 10 Desember 2020, dipublish: 30 Desember 2020

*Corresponding author: E-mail: maulana.arif.muhibbin-2019@psikologi.unair.ac.id

\begin{abstract}
Abstrak
Telaah literatur sistematis dalam penelitian ini bertujuan untuk mengetahui jenis jenis teknologi pendamping yang dapat diterapkan pada siswa dengan gangguan kesulitan belajar. Artikel dipilih melalui proses penyaringan pada tahun 2015-2020. Review dilakukan pada tiga database online yaitu Scince Direct, Sage Journal dan Proquest. Ada 7 artikel yang direview dari total 32 berdasarkan kriteria inklusi dan eklusi. Berdasarkan analisis dari artikel tersebut dapat diketahui bahwa intervensi digital seperti smartpen, PC, Smartphone yang terinstal aplikasi yang tepat dapat mendukung dan meningkatkan kinerja siswa dengan gangguan kesulitas belajar di bidang keterampilan belajar. Pengembangan intervensi digital pada spesifikasi tertentu terhadap siswa dengan gangguan kesulitan belajar perlu di terapkan dalam penelitian selanjutnya.
\end{abstract}

Kata kunci: Intervensi digital; Teknologi pendamping, Gangguan kesulitan belajar.

\begin{abstract}
The Systematic Literatur Review aims to reveal kinds of assistive technology that applied to students with a learning disability (LD) in several articles selected through the screening process in 2015-2020. The review was conducted on three online databases, they are ScienceDirect, Sage Journal dan Proquest. There were 7 articles reviewed from a total of 32 obtained from screening inclusion and exclusion criteria. Based on the analysis of several studies revealed that using digital intervention such as Smartpen, PC, and Smartphone which has had appropriate application, have supported and increased the performance of students with learning disabilities in the area of learning skills. The development of specific digital intervention on students with learning disabilities needs to be applied in future research.
\end{abstract}

Keywords: Digital intervention; Assistive Technology; Learning Disabilities

How to Cite: Muhibbin, M.A. \& Hendriani, W. (2020). Digital Intervention for Students with Learning Disabilities. Analitika: Jurnal Magister Psikologi UMA, 12 (2): 92 - 97 


\section{INTRODUCTION}

The use of digital technology has become an essential thing in modern life. More recent technologies such as smartpen, smartphone dan computers play a role for people with disabilities. These tools have the potential for providing effective instructional guidance for learning (Qahmash, 2018). In a special education context, these tools are known as assistive technology (AT), these tools are defines as any item, piece of device, or work system that increase or enhance capabilities of individual with disabilities (Erdem, 2017).

There are categories of AT, start with low-Tech devices wich typically nonelectronic components or electricity. Low Tech can be basic such as boards with pictures. The second is Mid-tech devices, developed tools using a digital system. Audiobooks, electronic storybooks are examples of Mid-tech. The newest AT is High-tech tools which are based on computer technologies. It can be a tablet, PC, iPad or smartphone device (Qahmash, 2018).

General educators or instructors in special education may be challenged to broaden their skills in teaching to accommodate the needs of students with learning disabilities (Bryant et al., 1998). Every person has different needs and variance learning styles. Current technologies such as mobile devices, computer, various educational application help student with disabilities to recognize the symbols, easy participation and comfortable in learning (Erdem, 2017).

Digital Interventions help students with learning disabilities to be more motivated in learning and practice more (Ok \& Bryant, 2016). According to its characteristics, students with learning disabilities have a disorder in one or more basic psychological processes related to understanding or using language, written or spoken which expose themself lack of ability to listen, read, speak, spell also calculations. Most people divided into three categories: Written language disabilities (dysgraphia), reading disabilities (dyslexia) and math disabilities or called dyscalculia (Ali \& Rafi, 2016)

Students who have special needs have to get special education and assistance from all elements. Services that can be given to students with LD are interventions, such as physical activities, verbal instruction, behavioral, metacognitive skills (Ontario Ministry of Children and Youth Services, 2009). Many individuals will get benefit from assistive technology such as a student with a disability from mild to severe. They are easy to survive in social life by the functions of technology (Reed et al., 2005). Interventions that using digital technology might give insight and crack the barriers associated with them (Sheehan \& Hassiotis, 2017).

Assistive Devices being predicted have a powerful impact to contribute to their learning, independence, and selfesteem student with learning disabilities (Reed et al., 2005). Therefore, a literature review of digital interventions for students with learning disabilities (LD) was used in this study.

This literature review aims to analyze digital interventions for students with learning disabilities (LD). The Types of intervention and the impact of the intervention were also analyzed according to the selected study criteria. This is done to provide an overview of digital 
interventions in enhancing the ability of students with learning disabilities in the areas study skills, then become a guide and reference in implementing interventions in similar contexts in the future.

\section{METHODOLOGY}

Literature in this paper was found using three online databases Science Direct, Sage Journal dan Proquest. This paper used the following terms: (Digital Intervention and Learning Disabilities) and (Digital Intervention or Learning Disabilities) and (Assistive Technology and Learning Disabilities) as Search keywords.

Some of the criteria in the search process consist of inclusion and exclusion categories. The inclusion criteria include;
Research that applied the process of Digital intervention; Participants focus on students with learning disabilities; Research from 2015 to 2020; Articles downloaded in full and literature used in English; Research using a literature review is allowed. While the exclusion criteria are articles that do not meet other inclusion criteria.

\section{RESULT AND DISCUSSIONS}

Seven studies were identified meeting the inclusive criteria were considered relevant with the review's vision to summarize the kinds of Digital Intervention in student with LD. The contribution given by the eight articles were presented in the following table.

Table 1. LD student challenges \& strategies

\begin{tabular}{|c|c|c|c|c|}
\hline Author (Year) & $\begin{array}{l}\text { LD student } \\
\text { challenge }\end{array}$ & $\begin{array}{l}\text { Devices } \\
\text { (AT) }\end{array}$ & $\begin{array}{c}\text { Strategies/software } \\
\text { /apps }\end{array}$ & Benefit for student \\
\hline $\begin{array}{l}\text { (Gonzalez-Ledo } \\
\text { et al., 2015) }\end{array}$ & $\begin{array}{l}\text { Students are } \\
\text { generally lower } \\
\text { in quality or } \\
\text { substance, and } \\
\text { less varied in } \\
\text { vocabulary. } \\
\end{array}$ & Computer & $\begin{array}{l}\text { Graphic organizer } \\
\text { and the narrative } \\
\text { writing diagram. }\end{array}$ & $\begin{array}{l}\text { The students can increase } \\
\text { the mean number of words } \\
\text { written and the amount of } \\
\text { time spent on planning. }\end{array}$ \\
\hline $\begin{array}{c}\text { (Straub \& } \\
\text { Vasquez, 2015) }\end{array}$ & $\begin{array}{l}\text { Students have } \\
\text { challenges at the } \\
\text { spectrum of } \\
\text { writing. }\end{array}$ & Computer & $\begin{array}{c}\text { Computer with } \\
\text { Educational e-book }\end{array}$ & $\begin{array}{l}\text { The student can increase } \\
\text { planning and spelling skills } \\
\text { in writing. }\end{array}$ \\
\hline $\begin{array}{l}\text { (Ok \& Bryant, } \\
\text { 2016) }\end{array}$ & $\begin{array}{l}\text { Students have } \\
\text { difficulties in } \\
\text { arithmetic. }\end{array}$ & iPad & $\begin{array}{c}\text { Application practice } \\
\text { teacher-directed } \\
\text { instruction. }\end{array}$ & $\begin{array}{l}\text { Students can improve fact } \\
\text { accuracy \& solving it in } \\
\text { arithmetic question }\end{array}$ \\
\hline $\begin{array}{l}\text { (Harper et al., } \\
\text { 2017) }\end{array}$ & $\begin{array}{l}\text { Students have } \\
\text { difficulty in } \\
\text { phonological } \\
\text { processing or } \\
\text { decoding. }\end{array}$ & Sma & $\begin{array}{l}\text { This pen is equipped } \\
\text { with a removable ink } \\
\text { cartridge, } \\
\text { microphone, audio } \\
\text { recording, speaker, } \\
\text { infrared camera \& } \\
\text { Internal memory. }\end{array}$ & $\begin{array}{l}\text { Students can increase } \\
\text { their independence, more } \\
\text { time for social activities, } \\
\text { and the ability to develop } \\
\text { strategies for homework } \\
\text { success }\end{array}$ \\
\hline $\begin{array}{l}\text { (Segal-Drori et } \\
\text { al., 2019) }\end{array}$ & $\begin{array}{l}\text { Students are low } \\
\text { in vocabulary } \\
\text { and story } \\
\text { listening. }\end{array}$ & Computer. & $\begin{array}{l}\text { Elektronik Book with } \\
\text { multimedia effect } \\
\text { (colors, sounds, } \\
\text { animation \& games) }\end{array}$ & $\begin{array}{l}\text { Students cam improve } \\
\text { metacognitive skills and } \\
\text { develop verbal ability. }\end{array}$ \\
\hline $\begin{array}{l}\text { (García-Redondo } \\
\text { et al., 2019) }\end{array}$ & $\begin{array}{c}\text { Students have a } \\
\text { deficit in } \\
\text { attention }\end{array}$ & smartphone & $\begin{array}{l}\text { Educational video } \\
\text { games }\end{array}$ & $\begin{array}{l}\text { Student can improve their } \\
\text { motivation and attention }\end{array}$ \\
\hline
\end{tabular}




\begin{tabular}{|c|c|c|c|c|}
\hline $\begin{array}{c}\text { (Satsangi et al., } \\
\text { 2019) }\end{array}$ & $\begin{array}{c}\text { Students low in } \\
\text { mathematical } \\
\text { concepts and } \\
\text { word problems. }\end{array}$ & smartphone & $\begin{array}{c}\text { Video-based } \\
\text { intervention with } \\
\text { algebra course as a } \\
\text { lesson. }\end{array}$ & $\begin{array}{c}\text { students can improve their } \\
\text { word ability \& problem- } \\
\text { solve in mathematic. }\end{array}$ \\
\hline
\end{tabular}

The Impact of Interventions

\section{Computer}

Using the computer to conduct Online Writing Instruction (OWI) significantly improve planning and spelling skill also amount the mean number of words student (Gonzalez-Ledo et al., 2015). Online environments provide a good advantage for writing instruction for students with learning disabilities such as flexibility in location and scheduling. It transfers well from traditional to online learning by procedural facilitation, scaffolding, and transcription (Vasquez \& Straub, 2016)

Through computers, students can access educational e-book which installed dictionary mode, automatic narrator story, and multimedia effect can improve students also nor ordinal numbers (Straub \& Vasquez, 2015). The student who lack an awareness of the audience and contain more spelling and sentence formation errors can be reduced by using automatic narrator wich installed in the computer (Gonzalez-Ledo et al., 2015). Educators should complete a computer by e-book for promoting emergent math, e-book must be adorned by a mathematical story which is illustrated by a funny picture that explains difficult words in the text of course. Otherwise, it can enhance metacognitive skill, and develop verbal ability student with LD (Segal-Drori et al., 2019)

\section{iPad}

Digital Intervention using iPad have similar strategies where student operates application which contain practice teacher-directed instruction for understanding the course. It significantly improves student accuracy and problemsolving arithmetic (Ok \& Bryant, 2016).

iPad focuses on instructional voice because it has a limited function than a smartphone. Using apps for instructional purposes in mathematics course are recommended for the student with $L D$ (Bouck \& Flanagan, 2009).

Arithmetic is a critical foundation skill for learning, student with learning disabilities often struggle to learn arithmetic (Ok \& Bryant, 2016). Speech recognition programs allow the student to dictate their answer (Bouck \& Flanagan, 2009). Teacher-directed instruction programs using iPad effectively help students with LD to be patient on their challenges in a lesson.

This program gives students with LD a chance to respond as well as quick feedback from the teacher and provide monitoring student progress (Ok \& Bryant, 2016). It improves student interest in multiple kinds of course including mathematic.

\section{smartphone}

The other type of intervention is using a smartphone. Mobile devices were to be a cultural mechanism that full engagement with students. It has multiple functions such as audio, recorder, and supports many applications. Serious games (SGs) by following guidance from the instructor can give a positive effect on students with LD (García-Redondo et al., 
2019). Educational Games provide meaningful content such as vocabulary, language learning, listening, spelling, and also a motivational aspect.

So that way it can improve student attention and motivation through educational games that are installed in smartphones (García-Redondo et al., 2019). Instructional video with certain lessons also can improve students in word ability and problem-solve in the calculation (Satsangi et al., 2016).

\section{smartpen}

The student with difficulties in decoding or memory will be helpful using smartpen, this pen contains digital effect and significantly enhance independence student in completing homework (Harper et al., 2017).

Smartpen or Livescribe Pen (LSP) allows the student to record audio synchronized with a pen that is written on paper. It is helpful for students who have difficulty in phonological processing or phonemic awareness to conduct self discover (Harper et al., 2017).

Learning disability affects people differently, in academic functioning students have trouble interpret words, complicated in reading, math, and following multiple steps (Ontario Ministry of Children and Youth Services, 2009). Advance technologies contributing to the independence of students with LD also their quality of life (Reed et al., 2005).

The findings supporting that assistive digital technology is effective as practice and remedial tool for reading, spelling deficits, fostering arithmetic skill, lack of attention especially for students with LD.

\section{CONCLUSIONS}

The study skills of students with LD can be improved and developed through digital Intervention using several Assistive Technology (AT) such as smartpen, iPad, mobile smartphone, and computer, and appropriate programs such as Online Writing Instruction (OWI), Educational e-book with multimedia effect, educational games. The impact of some of these interventions is very significant in increasing the performance and motivation, it also gives the student with LD hopes for chasing a better education.

The literature review is currently only done on 3 online databases with keywords search "Digital Intervention and Learning Disabilities" and "Digital Intervention or Learning Disabilities" and "Assistive Technology and Learning Disabilities". Some of the reviewed literature has been implemented in each region. It would be better for further research to be applied to specific areas in a narrow context.

\section{REFERENCES}

Ali, S., \& Rafi, M. (2016). Learning Disabilities: Characteristics and Instructional Approaches. International Journal of Humanities, Social Sciences and Education, 3(4), 111-115. https://doi.org/10.20431/23490381.0304013

Bouck, E. C., \& Flanagan, S. (2009). Assistive Technology and Mathematics: What is There and Where Can We Go in Special Education. Journal of Special Education Technology, 24(2), 17-30. https://doi.org/10.1177/01626434090240020 2

Bryant, D. P., Erin, J., Lock, R., Allan, J. M., \& Resta, P. E. (1998). Infusing a Teacher Preparation Program in Learning Disabilities with Assistive Technology. Journal of Learning Disabilities, 31(1), 55-66. 
Maulana Arif Muhibbin \& Wiwin Hendriani, Digital Intervention for Students with Learning Disabilities

https://doi.org/10.1177/002221949803100106 Erdem, R. (2017). Students with special educational needs and assistive technologies: A literature review. Turkish Online Journal of Educational Technology, 16(1), 128-146.

García-Redondo, P., García, T., Areces, D., Núñez, J. C., \& Rodríguez, C. (2019). Serious games and their effect improving attention in students with learning disabilities. International Journal of Environmental Research and Public Health, 16(14). https://doi.org/10.339o/ijerph16142480

Gonzalez-Ledo, M., Barbetta, P. M., \& Unzueta, C. H. (2015). The Effects of Computer Graphic Organizers on the Narrative Writing of Elementary School Students with Specific Learning Disabilities. Journal of Special Education Technology, 3o(1), 2942.

https://doi.org/10.1177/016264341503000103

Harper, K. A., Kurtzworth-Keen, K., \& Marable, M. A. (2017). Assistive technology for students with learning disabilities: A glimpse of the livescribe pen and its impact on homework completion. Education and Information Technologies, 22(5), 2471-2483. https://doi.org/10.1007/s10639-016-9555-0

Ok, M. W., \& Bryant, D. P. (2016). Effects of a Strategic Intervention with iPad Practice on the Multiplication Fact Performance of Fifth-Grade Students with Learning Disabilities. Learning Disability Quarterly, 39(3), 146-158. https://doi.org/10.1177/0731948715598285

Ontario Ministry of Children and Youth Services. (2009). A handbook on learning disabilities. Integra, $1-33$. https://www.childdevelop.ca/sites/default/ files/files/WAM LD handbook.pdf

Qahmash, A. I. M. (2018). The Potentials of Using Mobile Technology in Teaching Individuals with Learning Disabilities: A Review of Special Education Technology Literature. TechTrends, 62(6), 647-653. https://doi.org/10.1007/s11528-018-0298-1

Reed, P. R., Ph, D., \& Lahm, E. A. (2005). A Resource Guide for Teachers and Administrators about Assistive Technology. Assistive Technology.

Satsangi, R., Bouck, E. C., Taber-Doughty, T., Bofferding, L., \& Roberts, C. A. (2016). Comparing the Effectiveness of Virtual and Concrete Manipulatives to Teach Algebra to Secondary Students with Learning
Disabilities. Learning Disability Quarterly, 39(4), 240-253. https://doi.org/10.1177/o731948716649754

Satsangi, R., Hammer, R., \& Bouck, E. C. (2019). Using Video Modeling to Teach Geometry Word Problems: A Strategy for Students With Learning Disabilities. Remedial and Special Education. https://doi.org/10.1177/o741932518824974

Segal-Drori, O., Kalmanovich, L. B. H., \& Shamir, A. (2019). Electronic Book for Promoting Emergent Math: A Comparison Between Kindergarteners at Risk for Learning Disabilities and With Typical Development. Journal of Educational Computing Research, 57(4), 954-977. https://doi.org/10.1177/o735633118769459

Sheehan, R., \& Hassiotis, A. (2017). Digital mental health and intellectual disabilities: State of the evidence and future directions. Evidence-Based Mental Health, 20(4), 107111. https://doi.org/10.1136/eb-2017-102759

Straub, C., \& Vasquez, E. (2015). Effects of Synchronous Online Writing Instruction for Students With Learning Disabilities. Journal of Special Education Technology, 30(4), 213-222. https://doi.org/10.1177/o162643415618929

Vasquez, E., \& Straub, C. (2016). Online Writing Instruction for Children With Disabilities: A Review of the Empirical Literature. Reading and Writing Quarterly, 32(1), 81100. https://doi.org/10.108o/10573569.2014.95150 2 